\title{
form
}

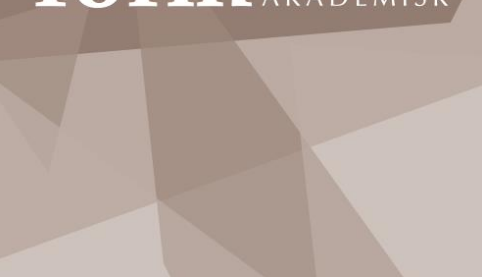

Vol I4, No 2 (2O2I)

\section{Fish skin, a sustainable material used from ancient times to today's fashion}

\begin{abstract}
The use of fish skin is an ancient tradition in Arctic societies along rivers, streams and coasts all over the world. Fish skins were regarded as a useful material for parkas, boots, mittens and hats. Today the interest in making use of fish skin, an undeveloped by-product, is on the rise. By using different tanning techniques from cultures around the globe, fish skin has shown great promise as a material for clothing, as well as other products. There is also a desire to be able to tan these skins with environmentally friendly techniques. Today most animal skins are tanned using chromium and other cheap toxic substances, raising question around health and environmental safety. The knowledge of how to use these traditional tanning methods has been preserved by woman from cultures along the Arctic Circle stretching from the Nordic countries to Canada and Japan. In order to keep this knowledge alive for future generations, Sweden has re-introduced the possibility to receive a Master tanner's title, increasing the incentive and status for those studying these important subjects. This is a report and narrative review of the field, and insights I have acquired over 3 decades; from student to Master Tanner.
\end{abstract}

Keywords:

Preserve, Research, Education, Sustainability, Fish leather.

\section{INTRODUCTION}

"Making something beautiful out of a hide is a way of honouring the dead animal," says Elisabeth Nibgoarsi from Arviat, Canada. This article aims to create an interest and understanding of skin preparation as a craft and to demonstrate that knowledge of how a garment or object is made can be as important as the object itself. My professional career started in an architect office: I had studied at gymnasium to become a building engineer. I worked like that for a few years, but in 1981 I heard about a course named Humans-Nature-Technology that was starting in January 1982. The teacher was Tomas Johansson, archaeologist at Jämtlands Läns Museum and founder of the Institute of Prehistoric Technology. The idea was to document, preserve and spread awareness of pre-industrial technology. I knew immediately that I wanted to take the course and I quit my job and now find myself writing this 38 years later. The course was 5 months long, and after that I was asked to become a teacher for next course in the spring of 1983. 
I worked with the course every spring for 10 years, and during the autumns I studied archaeology, travelled, and I eventually graduated as a Folk High School teacher. The first years I taught a number of prehistoric techniques, such as fire-building, ceramics, ironwork and tanning, but after a few years I became more and more concentrated on tanning. Much of my knowledge comes from visiting cultures where skins are still prepared using traditional methods: the Inuit's in Greenland and Canada, the Native Americans, the Ainu in Hokkaido and the Sami in Scandinavia.

\section{ARCHAEOLOGICAL FINDS}

There are very few finds of skins or leather from prehistoric times, but there is a lot of evidence of leather preparation from the tools that have been found, such as scrapers. Through the ages, people have made skin scrapers from stone, antler, bone, ceramics and iron (Fig 1).

Even very small pieces of flint or quartz can be used for skinning and scraping skin from small animals like birds, squirrels or cats. The scarp flint tools are even excellent for skinning the legs of bigger animals (Figure 2).

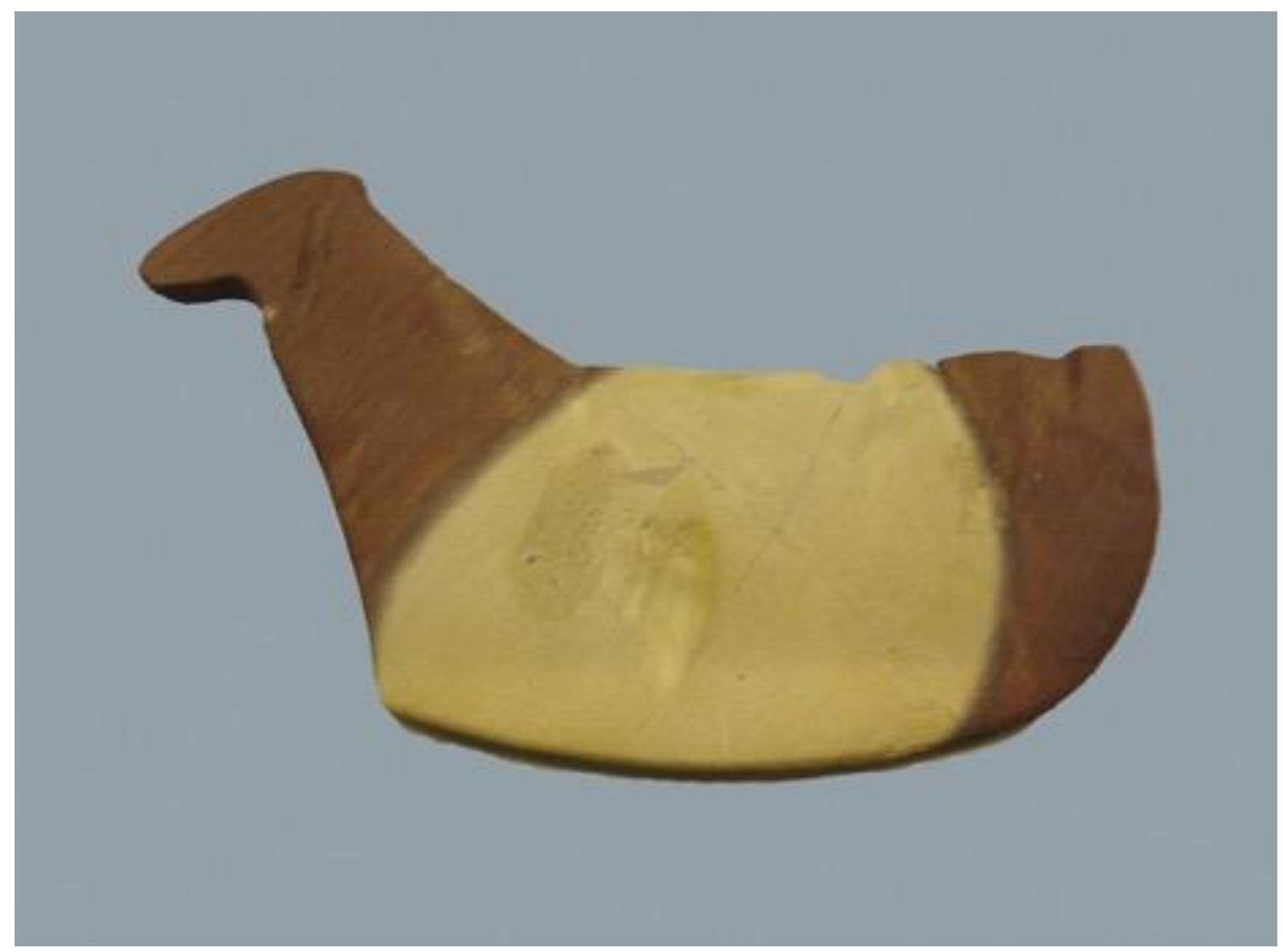

FIGURE 1. Slate knife dated to 5000-3000 B.C. Silver Museum, Arjeplog, Sweden (Rahme \& Hartman, 2014). 


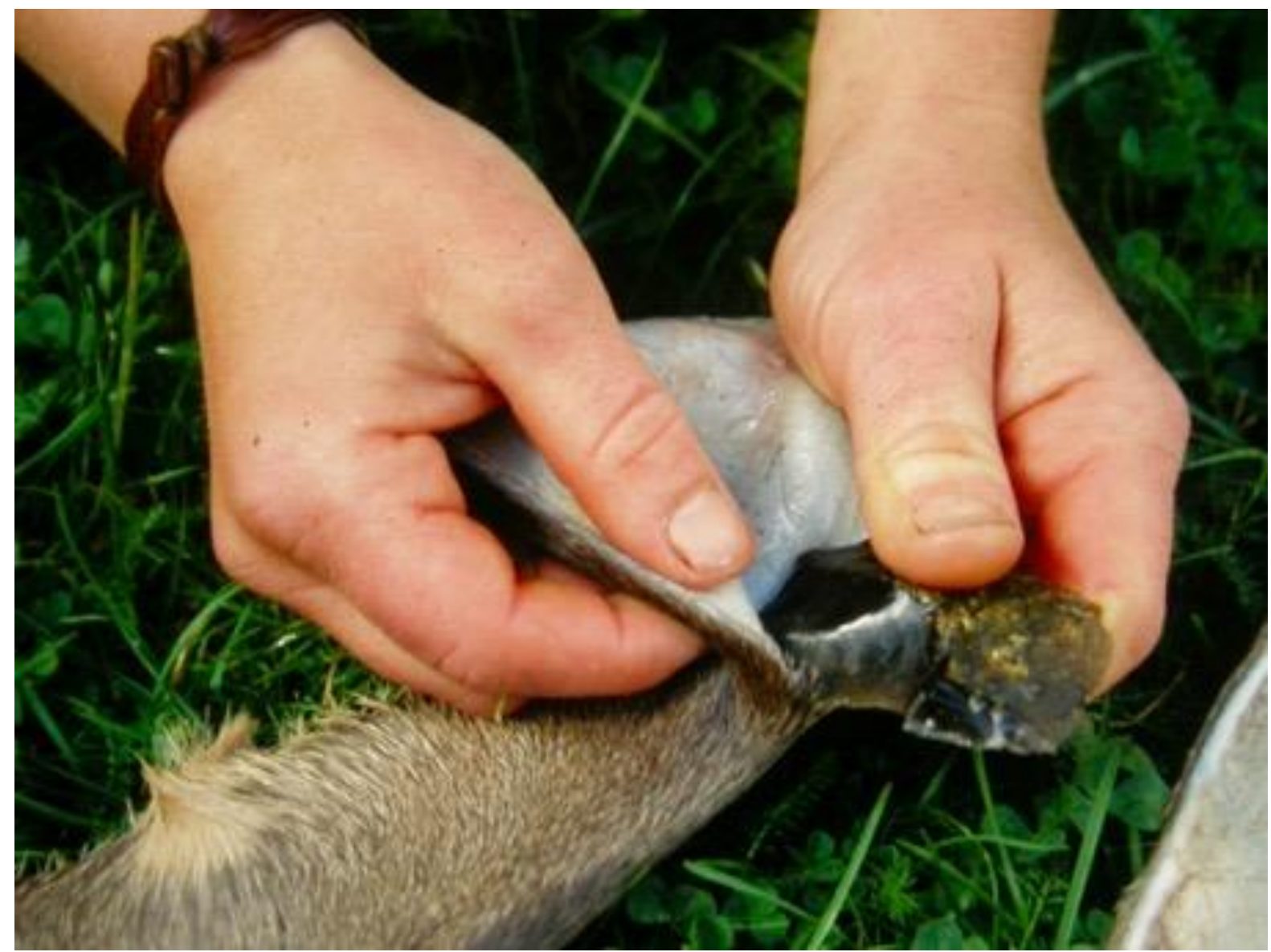

FIGURE 2. Flint tool (Rahme, 2011).

\section{TANNING METHODS}

Mechanical softening and the purpose of tanning. It is probable that hides were used at first without any sort of chemically processing. The skins were cleaned from dirt, fat and dried before they were softened mechanically, a method still used by the Inuit women in Arviat, Canada. In a raw hide the fibres are surrounded by ground substance (an amorphous gel-like substance) and water; when the hide dries and the moisture is removed, the soft fibres clump together and the hide becomes hard and stiff. The softening process is done by hand, by chewing or with different tools (Figure 3, 4, 5).

Hides that have only been softened mechanically decompose quickly, especially in warm and humid climates. In time it was discovered that using tanning agents lengthened the skin's lifespan. The objective of tanning is to cause various chemicals to react with the collagen chains and form bridges between components of the fibres, keeping them separated. This gives the fibres an open structure and makes the leather supple and pliable. Oil and smoke tanning were most likely the first tanning methods. 


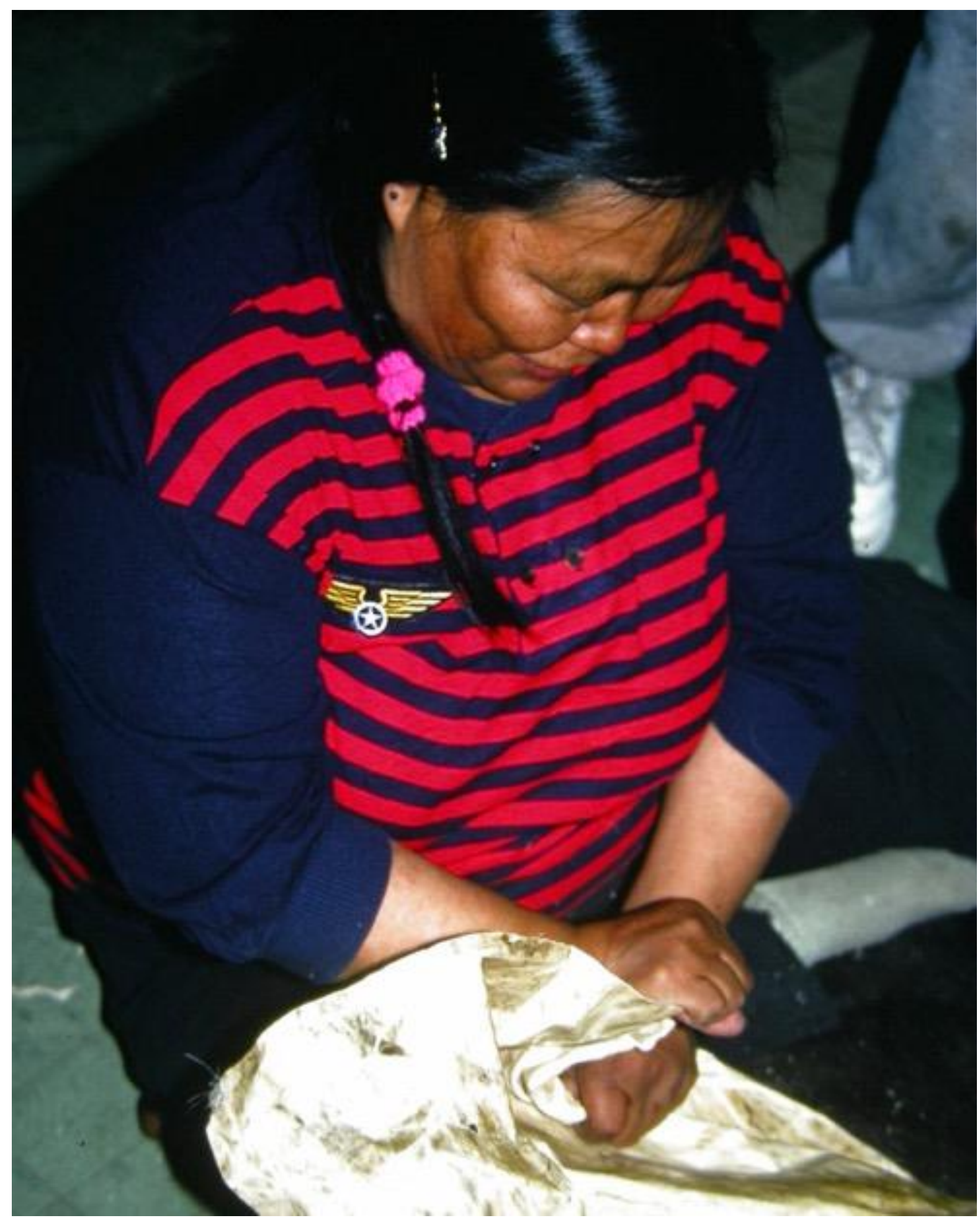

FIGURE 3. Lea softens a reindeer skin (Rahme \& Hartman, 2014). 


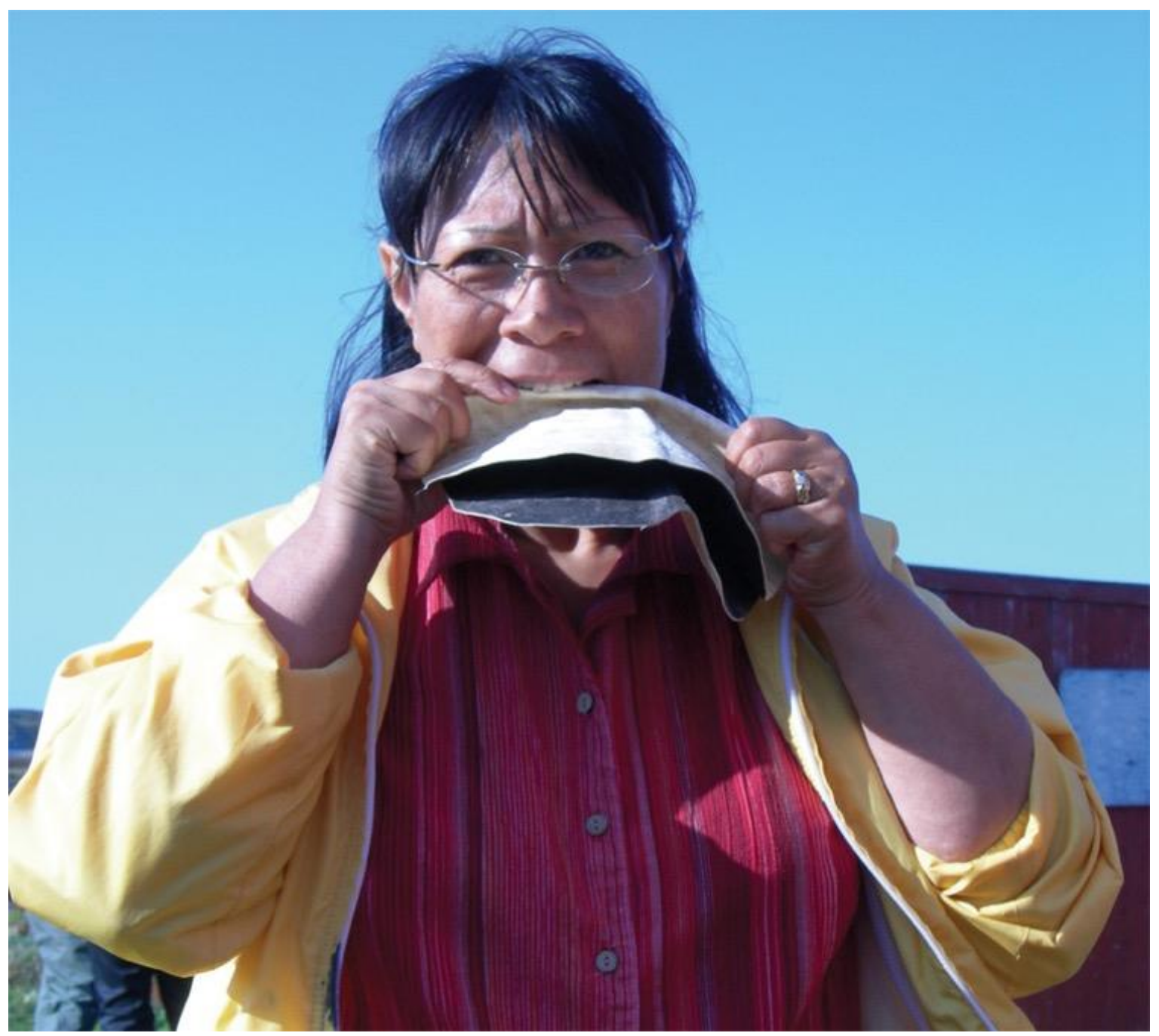

FIGURE 4. Rebekah chewing a sealskin sole (Rahme \& Hartman, 2014). 


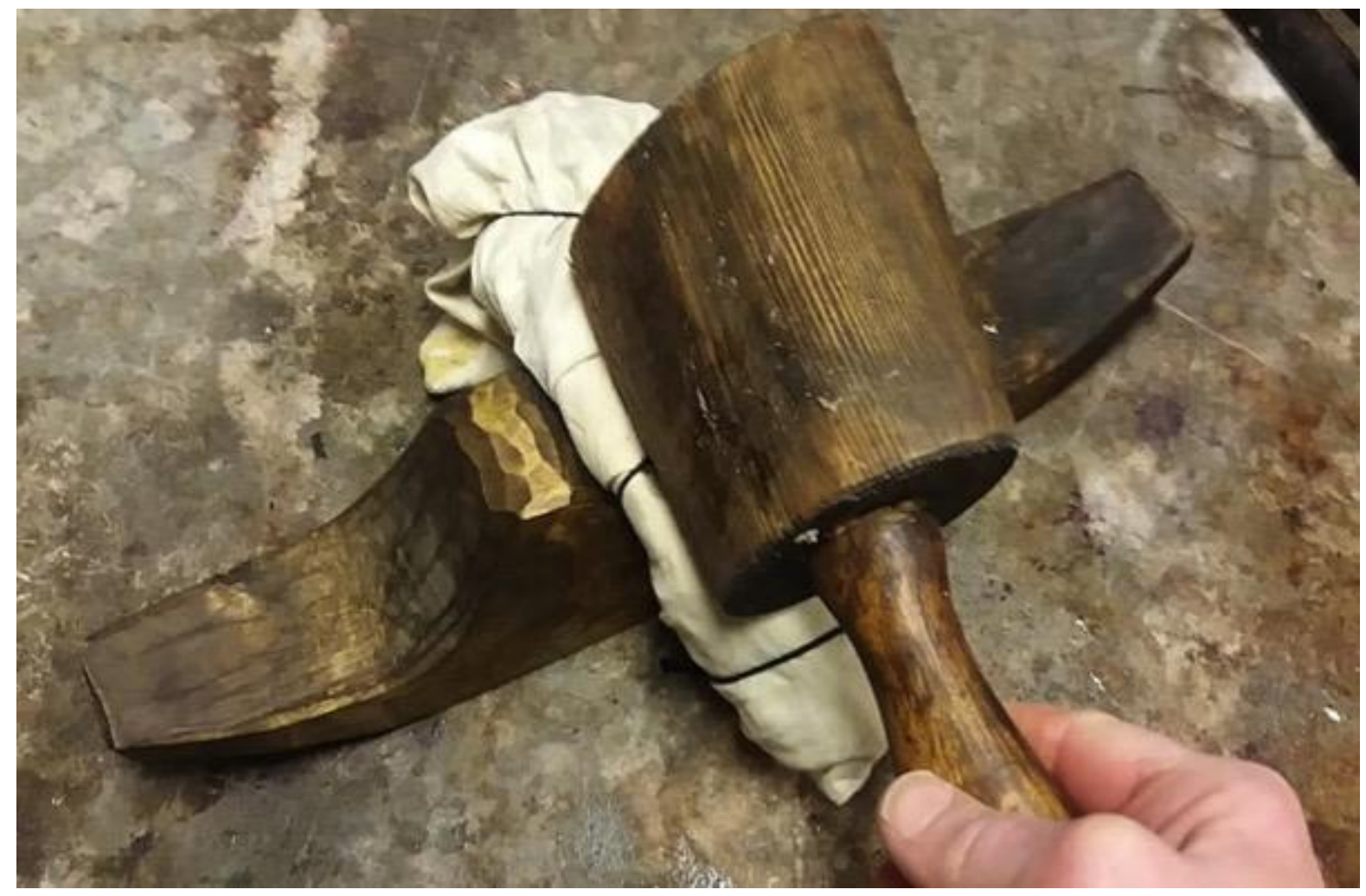

FIGURE 5. Wooden tool for softening fish skin.

\section{Oil tanning}

A number of different fats have been used to form the bridges keeping the fibres separated. Fats that are unsaturated and able to oxidize can under certain conditions of heat, acidity and mechanical processing, enter into a chemical bond with the hide. The result is yellowish, porous and soft leather (Figure 6).

This method is still in use today among some North American natives, for example the Dogrib tribe that hunt and fish between Great Bear Lake and Great Slave Lake in the Northwest Territories of Canada. There, a mixture of brain lard and soap is used to tan the hides. Originally, bone marrow was used instead of lard and ash lye instead of soap. In this area they have a saying "The animals brain is enough to tan its skin". The brain is an unsaturated phospholipid that binds chemically to the fibres in the hide. Phospholipids are easy to work into the hide and can help the saturated lard to penetrate the skin and fill up the spaces between the fibres. It is aiding the process if the mixture is alkaline. 


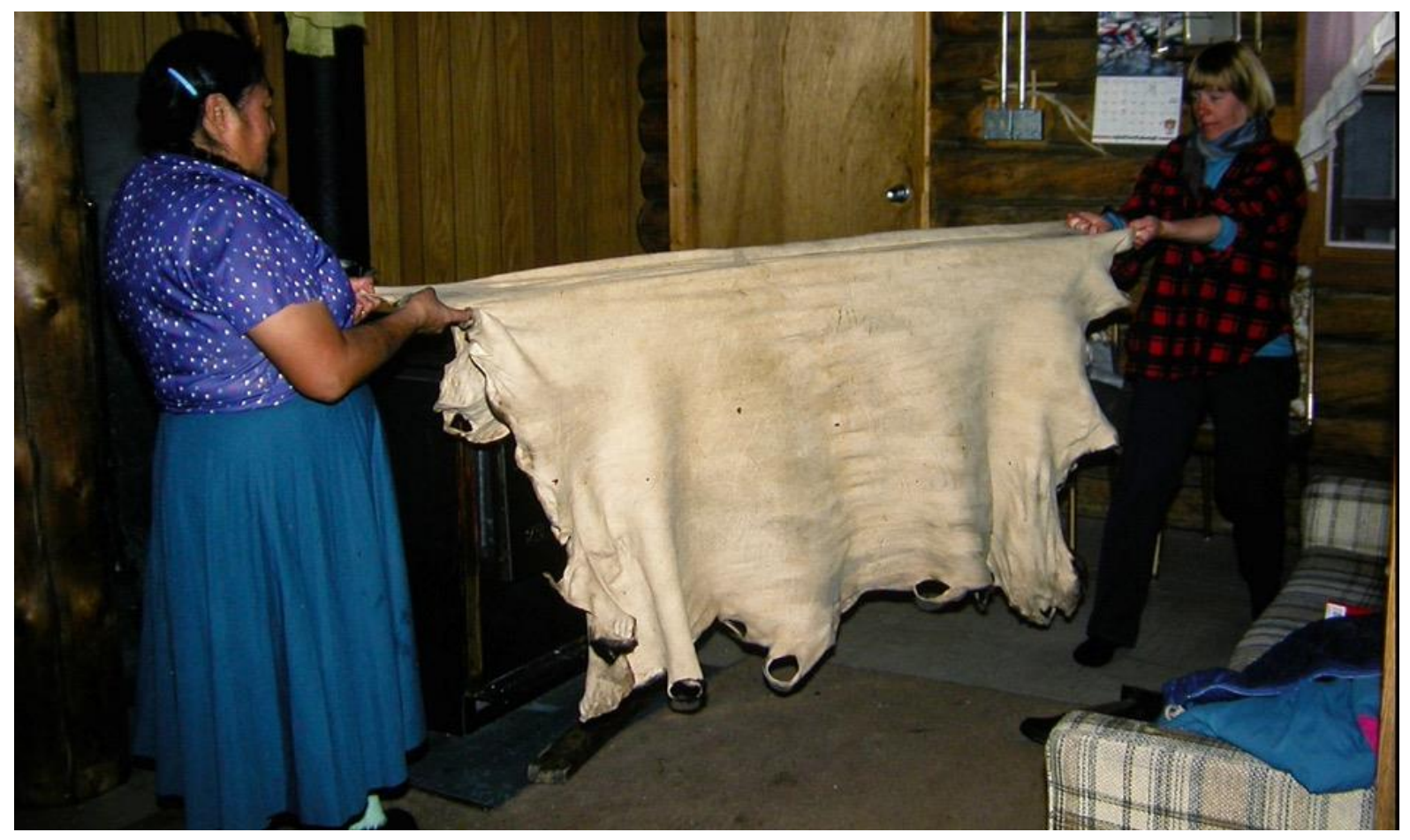

FIGURE 6. Stretching an oil-tanned moose hide (Rahme \& Hartman, 2014).

\section{Smoke tanning}

Smoking the leather, in addition to tanning it with oil gives the skin a pretty, golden brown colour and increases water resistance (Figure 7,8 ). If the skin gets wet it will not stiffen as it dries, instead it will remain soft. Formaldehydes in the smoke impregnate the skin making it more watertight. The smoke also prevents the growth of mould and bacteria on the skins. The smoke from burning woods contains various aldehydes where quantity differs depending on the wood type. Aldehydes contain carbonyl groups that react with amino groups in collagen to form a very stable bond. The tanning action of smoke is attributed mainly to the formaldehyde and other smoke substances known to have tanning power (Ts'ai \& Wilson, 1929). Smoke tanning has a long tradition even in both China and Japan. 


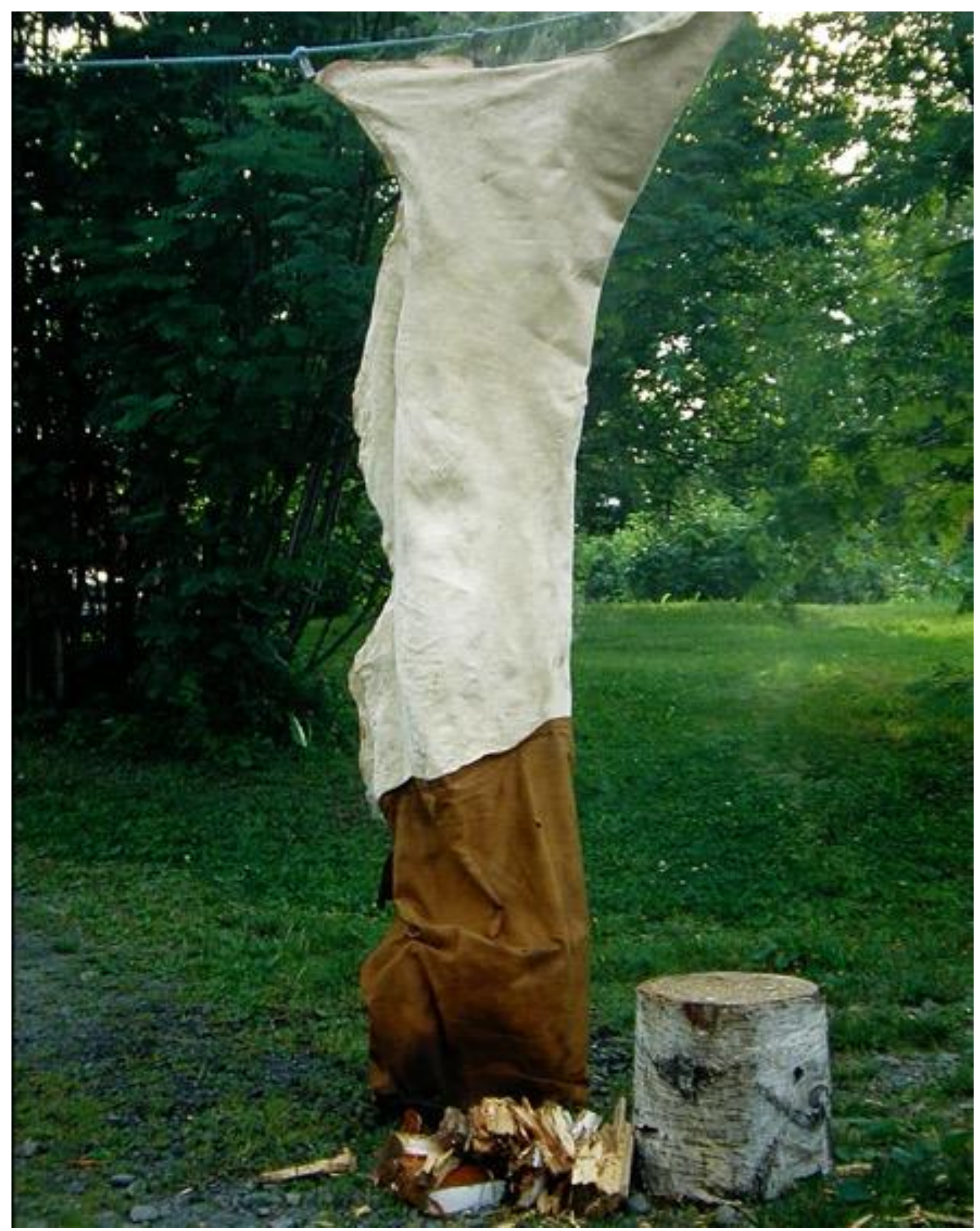

FIGURE 8. Smoking hide (Rahme \& Hartman, 2014). 


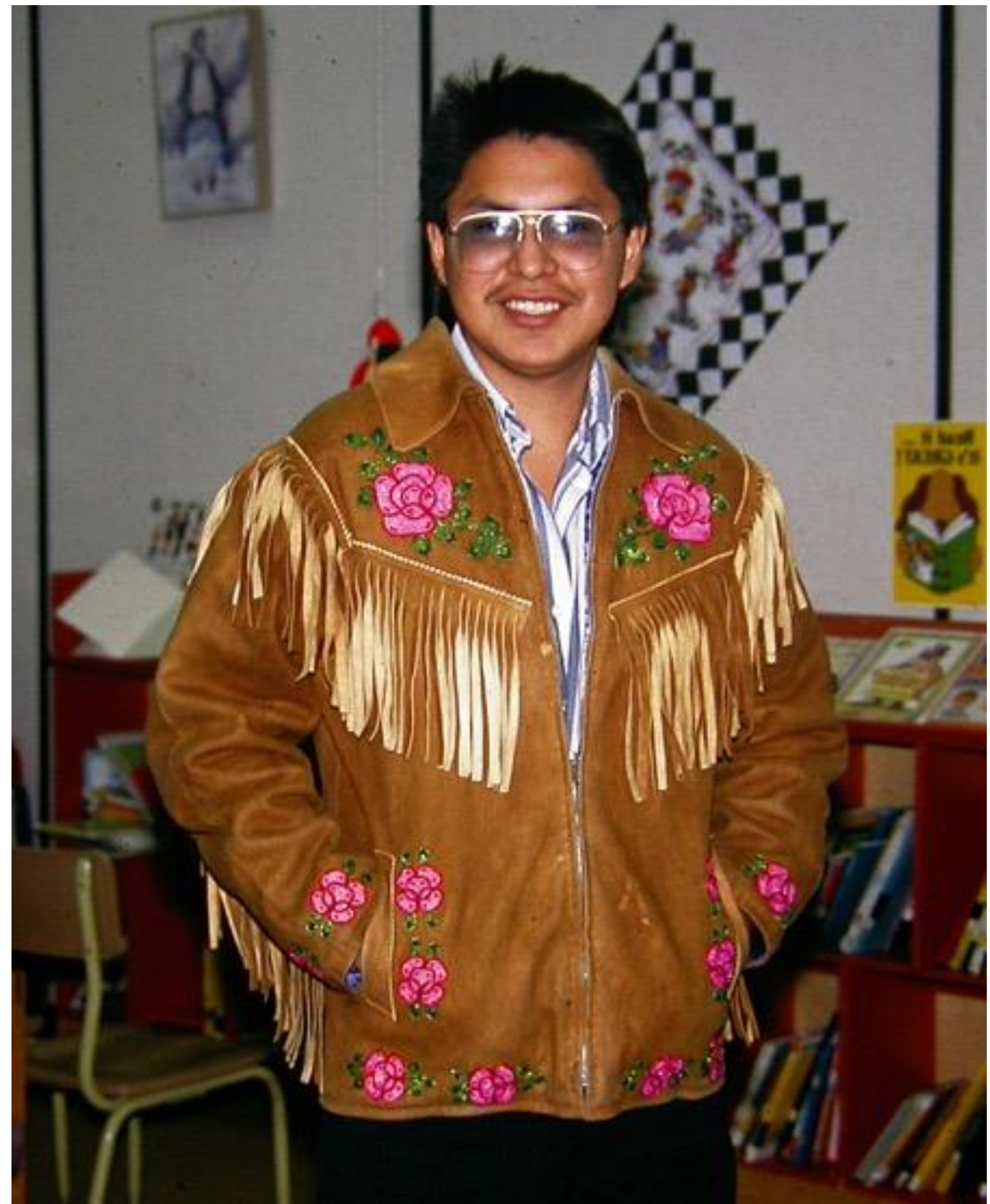

FIGURE 9. Jacket made from tanned and smoked moose hide (Rahme \& Hartman, 2014).

\section{Vegetable tanning}

The oldest indications of vegetable tanning were found in the remains of a tannery in Gebelien, Egypt, believed to be over 5000 years old. The findings from the site included tools, fully and half tanned skins together with a type of mimosa and oak bark. Vanity has been suggested as a cause of the discovery of vegetable tanning. It is possible that someone painted patterns on hides and eventually noticed that the parts, which had been painted, became softer and more durable than the unpainted parts. Vegetable tanned skin is durable, soft and water-resistant.

The vegetable tanning process works by binding tannic acid to the skin. Many vegetables contain both tannic acid and dyeing agents. Tannic acids are present in wood, bark, plants, fruit and 
roots worldwide. For tanning it is mainly bark from different trees, such as spruce, birch, oak, alder, rowan, sallow, willow, mimosa, and quebracho that has been used, but even bearberry leaves, heather, tormentil, sweet gale, wood hops and gallnuts contain tannic acid. Gallnuts from oak and sumac contain the highest naturally occurring level of tannins. "Gallnut shellac is known to have been used in various applications, especially in dyeing and tanning, since the Sumerian era" (Başaran \& Sarıkaya, 2015).

The tanning substances are mostly concentrated in the inner bark creating a barrier against microorganisms such as fungi and bacteria. For the most part, it makes no difference if the outer bark remains attached, but from birch and course spruce bark it is good to remove it. The tanning substance are weakly acidic and have a bitter astringent taste. The bark can be dried and saved for several years. It is easiest to peel off in the springtime, and that is also when the bark contains the most tannic acid.

Sprinkle tanning is thought to be the oldest method of vegetable tanning. To sprinkle tan a hide, place it in a hole in the ground or in a vat, and then sprinkle with finely ground, moistened bark. Additional hides are then added and sprinkled with bark consecutively until the hole is filled. Water and old bark liquor are then poured over the hides and the hole is covered with a lid. Tannin is slowly extracted from the bark, and binds with the hides. This method takes up to two years for coarser hides; the bark is changed 3-4 times during this period. Old and fresh barks are mixed in the initial stages of tanning, but only fresh bark is used towards the end. A way to shorten the tanning time is by boiling the bark with water and to put the skin in the cooled solution.

Today it is primarily the Sami in northern parts of Scandinavia that have preserved the traditional methods of bark tanning. With the Sami, as with the Inuit and the North American Indians, it is the women who tan skins and sew the clothes (Figure 10). 


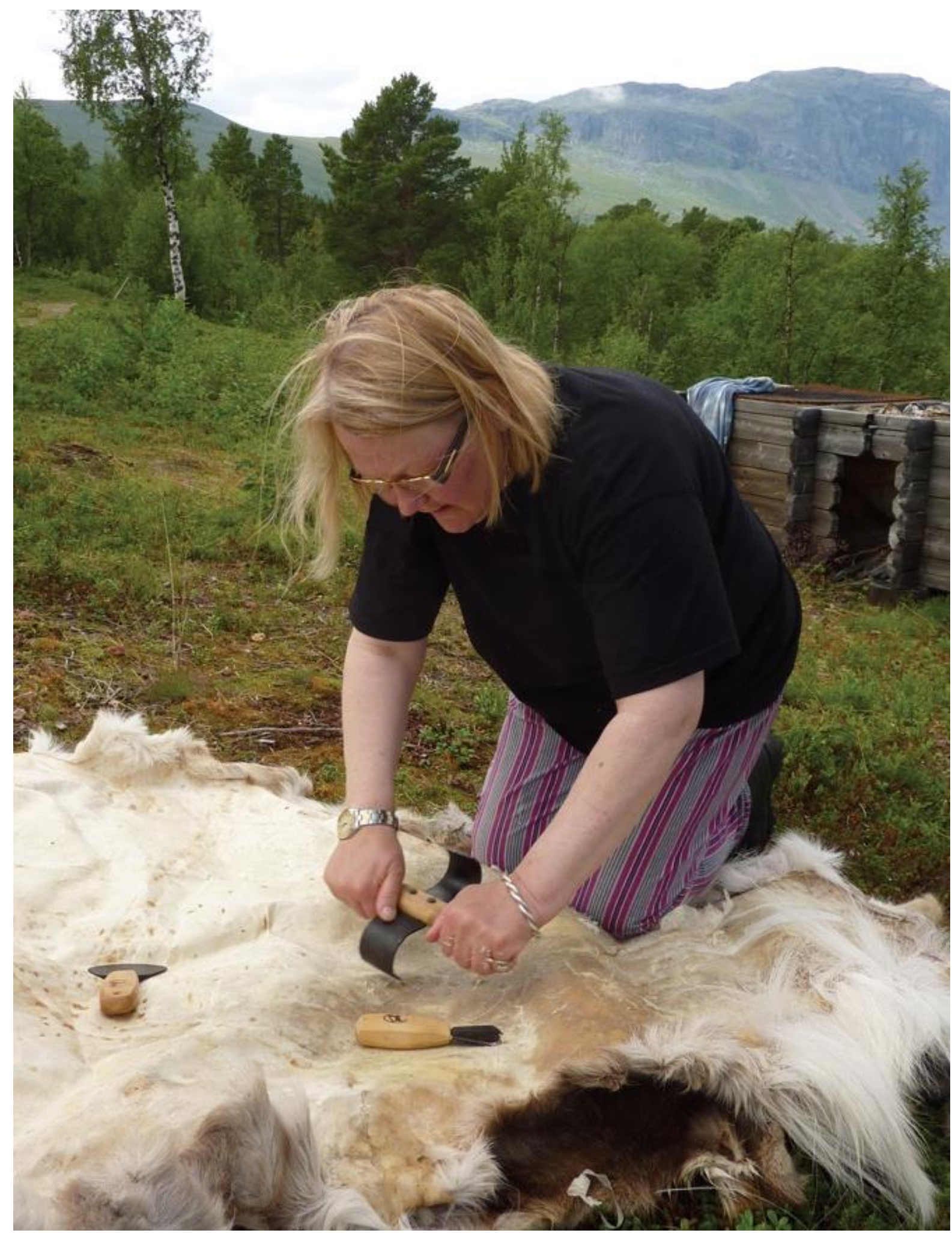

FIGURE 10. Laila Spik scraping a reindeer hide (Rahme \& Hartman, 2014).

\section{TRADITIONAL TANNING METHODS AND THEIR PLACE IN TODAYS SOCIETY}

The most environmentally friendly and sustainable tanning method is vegetable tanning that is done with bark. Chrome tanning is faster and cheaper and uses less water. Today as much as $90 \%$ of the world's leathers are chrome tanned. Chromium tanning uses a form of chromium called chromium 3. When leather tanned with chromium is handled incorrectly it is converted into a dangerous variant: 
chromium 6. Chromium 6 is carcinogenic, allergenic and dangerous for the environment. Therefore, always dispose chrome-tanned leather as hazardous waste. Chrome-tanned leather that ends up in landfills or in district heating systems risks releasing toxins we does not want in circulation. Vegetable tanned leathers are generally biodegradable. Interest in vegetable tanned leather is growing as environmentally friendly products are in demand and some tanneries are returning to vegetable tanning.

\footnotetext{
When preparing leather, several substances are used in addition to chromium that also can have environmentally or health-hazardous properties. Despite this, many people working in factories and tanneries handle chemicals that can be carcinogenic, allergenic and endocrine disrupting without protective equipment, which can seriously damage their health. It has been shown that lung cancer is more common in tannery workers than in the general population.

Some factories and tanneries also neglect to purify their wastewater before releasing it, which means that chromium and other problematic substances from the production end up in adjacent watercourses. The wastewater then pollutes the environment and can damage life in surrounding rivers and lakes. (Globala nyhetsbrevet)
}

The growing environmental awareness in the fashion industry has resulted in a great interest in fish skin as a sustainable material. Global production of fish has steadily increased over the last decade, and more than $50 \%$ of the total remaining material from fish capture results in 32 million tons of waste. A substantial amount of this waste is the skin of the fish; only a small percentage of this skin is processed into leather (Palomino, 2020).

In 2018 the EU project "Developing fish skin as a sustainable raw material for the fashion industry -Horizon H2020-MSCA-RISE-2018" was initiated by Elisa Palomino (Senior Lecturer BA Fashion Print, Central Saint Martins College of Art and Design in London). The partners in the project are from Great Britain, Israel, Italy, Japan and Island. Multiple universities, the leather industry and tanners with knowledge of fish skin tanning are represented.

Part of the project was to investigate if fish leather is waterproof, or if historically some kind of treatment has been used to make the fish skin more water-resistant. For the tests, processed skins from wild-caught salmons from the Bothnian Bay in Sweden were used. Skins from wild salmon appear to have slightly firmer skins than farmed salmon and it was important to make the tests as realistic as possible. The skins were prepared with different techniques taught from woman from ethnic minorities in Canada, Japan, Alaska, China and Scandinavia using traditional methods from their respective cultures. Three of the skins were also tanned with traditional tanning techniques for mammals adapted to the tanning of fish skins (Rahme \& Hartman, 2012/2021):

The different techniques/materials used were:

1. Mechanical softening.

2. Urine - as used by the Inuit in Canada.

3. Corn meal and mechanic softening - as used by the Hezhe in China,

4. Unsaturated fats - as used by North American Indians for their moose hide

5. Willow bark - as used by the Sami in Scandinavia.

6. Gallnut.

7. Rhubarb root.

In October 2019, the skins were brought to an analytical laboratory: Ars Tinctoria, in Santa Croce sull'Arno, Italy. Several different tests were performed, among them water resistance. The results showed that fish leather has a high breathability, is not water-resistant and the values obtained in terms of average tensile strength and percentage elongation, in most cases, are in line with the values obtained with bovine hides (Palomino \& Rahme, 2020). The salmon skin that was only mechanically softened was the most water resistant, but not enough to be called waterproof. Only one skin was prepared with each technique and it is thus difficult to draw firm conclusions from so few samples. 
The results however, show the potential use for fish skin in modern fashion/cloth production as an alternative to other types of leather.

\section{The guild system}

Wall paintings depicting a tannery can be seen in the tomb of Rekhmires, Thebes, Egypt, around 1450 B.C. (Waterer, 1956) (Figure 11). This is the oldest picture currently known that portrays leather workers. The tools used are remarkably similar to those many leatherworkers use today (Figure 12).

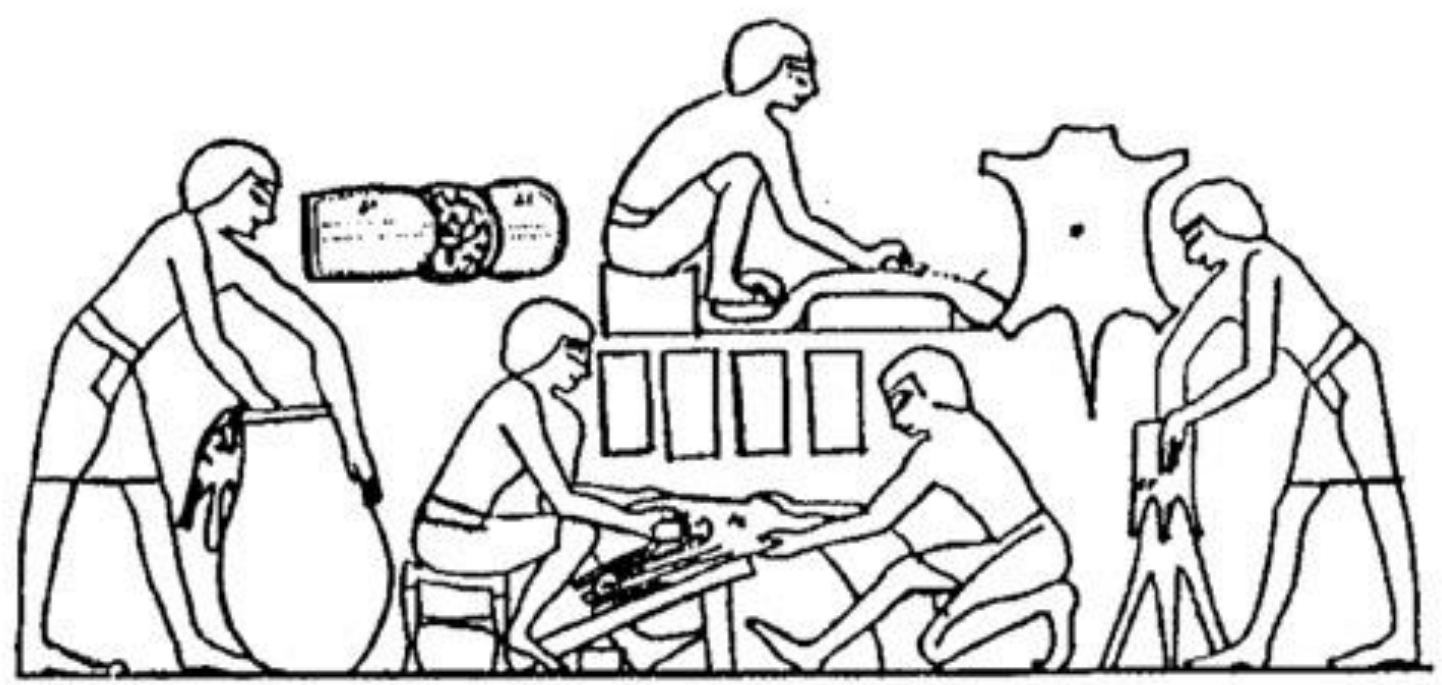

FIGURE 11. Egyptian leather-dress (Waterer, 1956).

Keeping the knowledge of traditional tanning techniques alive today is important. A good way to not lose this knowledge is to increase the incentive, and status, surrounding tanning. Receiving a master tanner's title was possible in Sweden up to 1995 when the opportunity was removed on the initiative of the tannery industry. The last time a Master tanner's title was awarded in Sweden was in 1956.

The first written evidence in Sweden that tanning was beginning to be regarded as a profession, and consequently a male occupation (in contrast to it previously being a female dominated craft through history), come from the 14th-century city code of Visby, Sweden.

By the twelfth century, the guild system had begun to develop on the continent and had spread gradually to the Nordic countries. The guild was a collection of masters within the same, or closely related, trades that promoted product quality, work for fixed prices and settled working conditions. The word "skrå" ("guild"), in Swedish is Old Norse and means "prepared skin". Originally, the word referred to the parchment on which the guild's charter was written. 


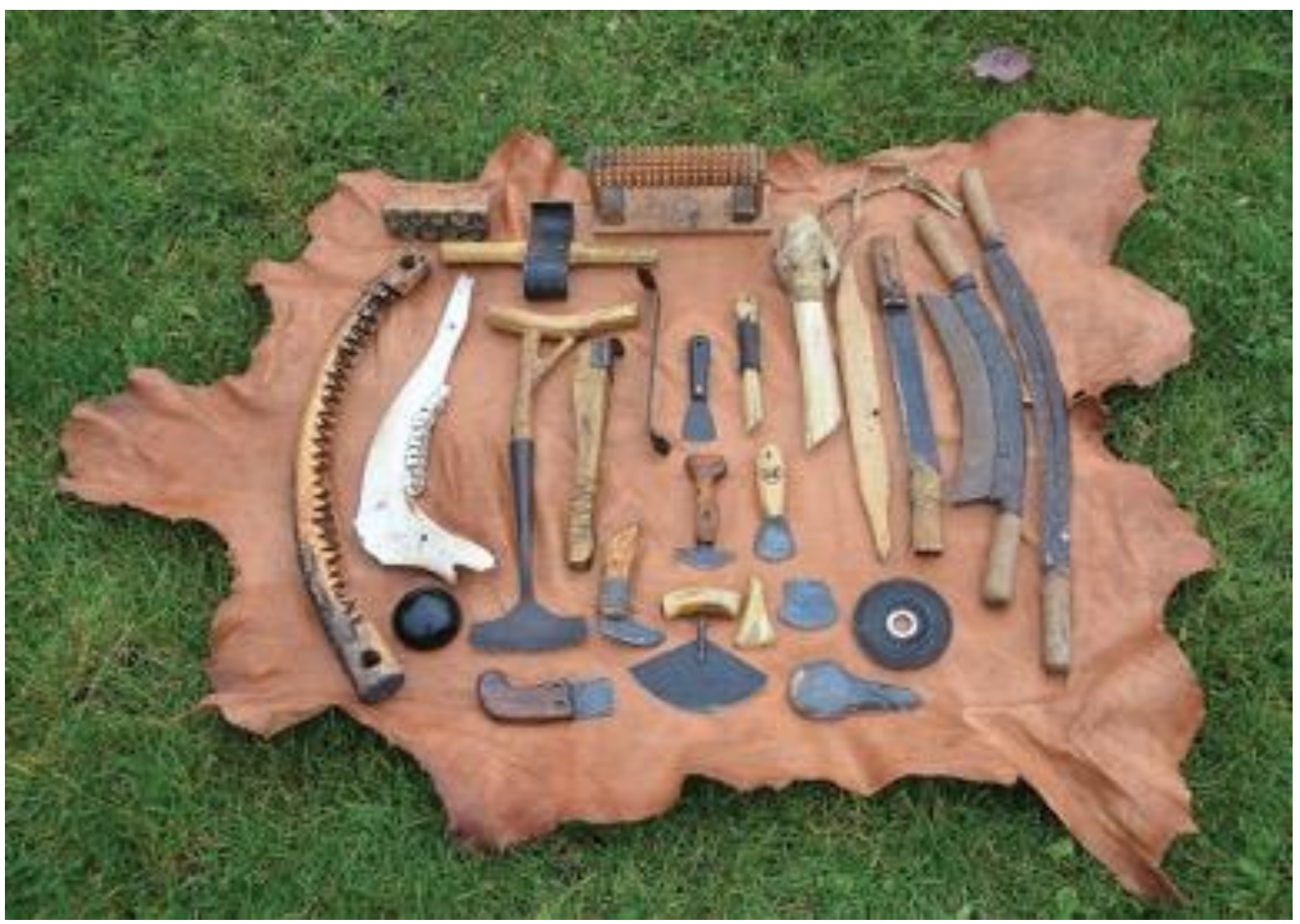

FIGURE 12. Tools for tanning (Rahme \& Hartman, 2014).

The guild also had a social task. They cared for their sick members, arranged for the education of fatherless children, and helped widows if they could not support themselves. If the widow knew the profession, she had the right to inherit the husband's bursary, which meant that she was given the right to take over the husband's craft. Tanners in Malmö established their first guild in 1429; the tanners were to work with furry skins, but also had the right to make chamois leather. Makers of Cordovan leather, who prepared finer, often dyed, leather, first appeared in Stockholm in the late 14th century. Originally, shoemakers tanned their own leather. However, a group of specialists in bark tanning gradually evolved and formed their own professional group in the 17th century. Also in the 17th century, there appeared a special guild for makers of chamois who worked with oil tanning. A negative factor with Guilds, however, was the monopoly embodied in mandatory guild membership that restricted free competition. The guild made sure that they did not become too many masters. Each guild decided which tests a journeyman had to complete to become a master and to practice the profession. The requirements for Danish rug makers in 1686 were that a candidate had to prepare an elk hide, three buffalo hides, two deerskins, ten goatskins, ten cowhides, and ten calfskins. From these skins he then had to make a buff coat, a carbine strap, a long sword harness, two pairs of gloves and a pair of leggings. The tasks were so hard that it was nearly impossible to complete them successfully, and thus the number of masters was kept low (Rahme \& Hartman, 2014, Bertel, 1949).

It was said in the 17th century, "In Sweden one can strive hard and become king, but one cannot become a chamois maker." It was easier for one who was a master's son or married to a master's daughter. One could also become a master by "keeping" a widow, which meant marrying the widow of a deceased master. (Bertel, 1949)

Between 1871 and 1875 there were 687 tanneries in all of Sweden. When the processing of skin became more technically complicated and required larger and larger capital investments, the smaller tanneries had difficulties keeping up with the developments and were gradually closed and replaced 
by a few large factories. From the 1890's on, rubber boots began to take the place of bark tanned, water-resistant leather boots, which led to a smaller demand for bark tanned leather among the tanneries of the farm settlements. The early 1900's have been called the death-decade of tanning; in 1913 the number of tanneries had sunk to 136, and today there are less than ten tanneries of varying sizes (Rahme \& Hartman, 2014).

In 2019 the opportunity to receive a Master tanner's title was re-introduced in Sweden. Following an initiative by Lotta Rahme, Guest Craftsman at the University of Gothenburg, collaboration with the National Association of Swedish Handicraft Societies, the Swedish Craft Council and Bäckedals Folk High School was initiated. The school offered to be responsible for the journeymen's training and guidelines were decided on which tests a journeyman had to complete to practice the profession and to become a master. In November 2019, Lotta Rahme and Aja Pettersson, tanning teacher at Bäckedals FHS, received their Master tanners diplomas and in September 2020, 2 students received their journeyman's certificate.

\section{Intangible cultural heritage}

In March 2020 traditional tanning was deemed an Intangible Cultural Heritage in Sweden under the Institute for Language and Folklore. In China the skill of processing fish skin was listed as Intangible Cultural Heritage 2006.

\section{CONCLUSION}

Knowledge of pre-industrial everyday technology is important in the world today; it helps us to understand our own history and to realize how dependent we are on nature of which we are a part. Today's industrial leather production often uses toxic and environmentally dangerous chemicals when preparing hides. The traditional tanning methods around the world can provide us with useful, safe alternatives and it is important that the knowledge of the craft is preserved. Fish skin is a raw material that, today is regarded by many as a waist product. The 2018 EU project "Developing fish skin as a sustainable raw material for the fashion industry" has shown the potential use of fish skin as an alternative to other leathers in modern fashion/cloth production. To preserve the knowledge of traditional tanning techniques alive the opportunity to receive a Mastership diploma as a tanner was re-introduced in Sweden 2019. 


\section{REFERENCES}

Başaran, F. N., \& Sarıkaya, H. (2015). Investigation of nutgall and some natural dyes with mordants cotten dyeing and fastness level in the context of the ecological textile production. IJASOS-International E-Journal of Advances in Social Sciences, 1(3), 452-459. https://doi.org/10.18769/ijasos.00057

Bertel, G. (1949). Från djurhud till modern lädervara: Del 2. Gothia.

Globala nyhetsbrevet. (n.d.). Så tillverkas läder. The Swedish Society for Nature Conservation. https://www.naturskyddsforeningen.se/lader

Palomino, E. (2020). SDG 14 Life Below Water: Introducing fish skin as a sustainable raw material for fashion. In I. B. Franco, T. Chatterji, E. Derbyshire, \& J. Tracey (Eds.), Actioning the Global Goals for Local Impact (pp. 229-246). Springer Singapore. https://doi.org/10.1007/978-981-32-9927-6_15

Palomino, E., \& Rahme, L. (2020). Indigenous arctic fish skin - A study of different traditional skin processing technology. Society of Leather Technologists and Chemists Journal from Northampton University, accepted for publication.

Rahme.L (2011). Tanning with traditional tools and techniques. Leather tanneries: the archaeological evidence, 39-48.

Rahme, L., \& Hartman, D. (2021). Fish leather: Tanning and sewing with traditional methods. Lottas Garfveri. (Original work published 2012)

Rahme, L., \& Hartman, D. (2014). Traditional tanning: Leather and furskin. Lottas Garfveri.

Ts'ai, L. S., \& Wilson, E. O. (1929). Smoke tannage: The effect of wood smoke on the combining capacity of hide substance for chromic trioxide, vegetable tanning, and sodium hydroxide. Journal of the American Leather Chemists' Association, 21-36.

Waterer, J. W. (1956). Leather: History of technology (Vol. 1-2). Clarendon Press. 